\title{
Political vandalism as counter-speech: A defense of defacing and destroying tainted monuments
}

\section{Ten-Herng Lai ${ }^{\circ}$}

School of Philosophy, Australian National University, Canberra, Australian Capital Territory, 2601, Australia

\section{Correspondence}

Ten-Herng Lai, School of Philosophy, Australian National University, Canberra, ACT, Australia.

Email: ten-herng.lai@anu.edu.au

\begin{abstract}
Tainted political symbols ought to be confronted, removed, or at least recontextualized. Despite the best efforts to achieve this, however, official actions on tainted symbols often fail to take place. In such cases, I argue that political vandalism-the unauthorized defacement, destruction, or removal of political symbols-may be morally permissible or even obligatory. This is when, and insofar as, political vandalism serves as fitting counter-speech that undermines the authority of tainted symbols in ways that match their publicity, refuses to let them speak in our name, and challenges the derogatory messages expressed through a mechanism I call derogatory pedestalling: the glorification or honoring of certain individuals or ideologies that can only make sense when members of a targeted group are taken to be inferior.
\end{abstract}

We inherit numerous political symbols from the past in the form of statues, monuments, public holidays, and road names, just to name a few. Many of these symbols are relatively innocuous. Yet others are associated with ideas or figures that many find highly and unjustly offensive. What is the appropriate response to these contested political symbols?

There are a number of different ways in which we might respond to problematic political symbols. We might keep them as part of our cultural heritage, like the "Hitler Bell" still hanging in Herxheim am Berg, Germany. Or we might continue to honor them in the highest manner possible, as in the case of the Chiang Kai-shek Memorial Hall in Taiwan, which is guarded by ceremonial guards and displays a tourist-attracting changing of guards hourly. But sometimes contested political symbols face a different fate. Confederate symbols in the United States, Captain Cook statues in Australia, and several less well-guarded Chiang Kai-shek statues in Taiwan have all faced numerous successful acts of vandalism, ranging from being dressed up in humiliating outfits, having messages spray-painted on them, to beheading.

I am interested in this last type of reaction: political vandalism-the unauthorized defacement, destruction, or removal of political symbols. Many have argued that certain political symbols in the form of statues and monuments are morally tainted and ought to be confronted, removed, or at least recontextualized (Burch-Brown, 2017; Frowe, 2019; Nili, 2020; Schulz, 2019; Timmerman, n.d.). I shall argue that when official acts of confrontation, removal, or recontextualization fail to take place, political vandalism may sometimes be permissible or even 
obligatory, as it can serve as fitting counter-speech that prevents or mitigates the objectionable things state-sponsored tainted political symbols do. Through reaching this conclusion, I also attempt to bridge a gap between political theory and real-life activism. While there is indeed a growing literature on the morality of political symbols, political vandalism as a form of activism is virtually absent from the literature on civil and even uncivil disobedience, despite the regular occurrences of this type of activism around the world. ${ }^{1}$

I attempt to bridge this gap by drawing insight from speech act theories in order to explain the particular mechanisms through which political symbols can do problematic things and how they can be countered. More specifically, I will point out that state-sponsored tainted political symbols speak, sometimes indirectly, purportedly in our name with considerable authority and publicity. These features not only contribute to the effectiveness of state-sponsored tainted political symbols, but also are exactly where vandalism as a form of counter-speech can work to undo the force of tainted political symbols.

The plan is as follows. In Section 1, I will very briefly explain when political symbols are tainted and thus should be confronted, removed, or at least recontextualized. In Section 2, I will provide a detailed account on how tainted symbols express derogatory messages. In Section 3, I argue that political vandalism can serve as fitting counter-speech against tainted symbols, and can be morally permissible or even obligatory. In Section 4 , I respond to a number of objections.

\section{1 | TAINTED POLITICAL SYMBOLS}

Many have argued that certain statues, monuments, public holidays, road and street names, the printing or imprints on cash or coins, or political symbols in general, are tainted-because they harm (Timmerman, n.d.), are symbolic of objectionable ideologies (Burch-Brown, 2017), degrade and/or alienate (Schulz, 2019), reinforce dubious moral commitments (Nili, 2020), or express positive attitudes towards those who have committed serious human rights violation (Frowe, 2019), just to name a few-and thus ought to be confronted, removed, or at least recontextualized. Here I will only briefly introduce one: Johannes Schulz's (2019) proposal that commemorations are tainted when they either degrade or alienate.

A political symbol degrades when it is "expressive of an ideology that is both disrespectful and expressively connected to an existing and wrongful social hierarchy" (Schulz, 2019, p. 168). For instance, Captain Cook statues engraved with "Captain James Cook Discovered Australia 1770" express an ideology that Australia may, at that time, be treated as terra nullius (unowned land), and that British colonizers may take whatever they please and claim ownership over the land. This ideology presupposes that Indigenous Australians were either nonexistent or unqualified as full human beings to have a legitimate claim over the land which they lived upon. Nowadays, Indigenous Australians are still situated at an inferior position within the actual social hierarchies of Australia. For example, Indigenous Australians are imprisoned at a rate 13 times higher than non-Indigenous Australians (Fitzgerald, 2009), and there still are significant gaps between Indigenous and non-Indigenous Australians in areas such as wealth and income, education, and health (Australian Institute of Health and Welfare, 2019).

A political symbol alienates when it fails to secure, or even actively undermines, "the idea that all persons have equal standing in the moral community" (Schulz, 2019, p. 173). For example, as part of the remnants of what TayIor (2006) calls a "personality cult" that was "promoted by the central government (and Chiang [Kai-shek] himself)" (p. 96), in Taiwan the Chiang Kai-shek Memorial Hall honors Chiang as "the beacon of freedom" and "the savior of the nation." While Chiang indeed "had to consolidate control over the island ... most agree his methods were excessive": the estimation of civilians killed in the 228 Massacre that occurred in 1947 "ranges from 2,000 to more than 25,000"; during the 38 year-long "White Terror" he initiated thousands were tortured and murdered; "[u]nder his hands, many jail sentences were converted to death sentences." ${ }^{2}$ Here, surviving victims and their family members can reasonably feel that the wrongs they have endured were not taken into consideration when the Memorial Hall was erected, and may continue to reasonably feel alienated as long as the monument remains as it is. 
Again, this is but one of the many plausible accounts of why some political symbols are tainted and thus ought to be confronted, removed, or at least recontextualized. Even if we disagree with the details of this account, we may still generalize the lesson as something like this: insofar as political symbols express significant derogatory messages, official action on it ought to take place. However, sympathizers of these tainted symbols, typically dominant groups in the society, often refuse to give ground, and the prospects of official removal, recontextualization, or even a simple acknowledgment that something may be problematic are dim. Captain Cook statues, the Chiang Kai-shek Memorial Hall, Confederate monuments, and many other tainted monuments still stand today. We may thus wonder what courses of actions we may then take. In the next section, I will engage with the question: "how do tainted symbols express derogatory messages?" as the answer to this question will prove instructive to how individuals may confront tainted political symbols.

\section{I HOW TAINTED POLITICAL SYMBOLS WORK}

How do tainted symbols express derogatory messages? My answer comes in two parts. First, I will draw a parallel between hate speech and tainted political symbols, and propose the concept of "derogatory pedestalling," that the glorification or honoring of certain individuals or ideologies can only make sense when members of a targeted group are taken to be inferior. Second, many tainted symbols are state sponsored, and in virtue of being instances of state speech, they gain additional force.

\section{1 | Derogatory pedestalling}

Sometimes hate speech is blatant and outright, but sometimes they can be somewhat indirect. Gelber and McNamara (2016) provide a useful example:

People yelling hate speech (e.g., "fucking Jew," "heil Hitler") out of car windows when a man walks home from the synagogue on Friday evenings with his children, who get quite scared and intimidated (p. 333).

As they observe, both "fucking Jew" and "heil Hitler" constitute hate speech. The former is obviously hate speech because it targets an oppressed group. However, the latter is also hate speech because it salutes an unjust oppressor of the group targeted by the former. Indeed, even without the former, the latter is still hate speech because the glorification of Hitler constitutes both an endorsement and a legitimization of Nazism. Among other things, "heil Hitler" indirectly declares that members of the oppressed group are inferior, of less or no moral worth, or not victims at all but rather liable to be tortured and killed.

This is an instance of what I call derogatory pedestalling:

by saluting, glorifying, or honoring an unjust oppressor or ideology, speakers indirectly rank their target(s) as inferior, convey hostility, or implicitly insult and assault their target(s).

Similar to the more indirect instances of hate speech, tainted political symbols can convey the inferiority of certain groups by saluting, glorifying, or honoring an unjust oppressor or ideology. Honoring Captain Cook's "discovery" of Australia only makes sense if Indigenous Australians were nonexistent; portraying Chiang Kai-shek as the indisputable "savior" only makes sense if those who were killed unnecessarily on his orders were expendable. In short, tainted political symbols express derogatory messages via derogatory pedestalling. 


\subsection{State-sponsored tainted symbols}

Many tainted monuments are established or maintained by the state, and thus instantiate the properties of state speech. Here I will highlight four important features: state-sponsored symbols enjoy considerable authority and publicity, sometimes speak indirectly, and purport to speak in our name.

State speech is the paradigm of speech with authority. Within a fairly wide range, when the state declares suchand-such, if such-and-such was not already the case, it becomes the case. For example, if the state declares that it is a state of emergency, it becomes the case, if it wasn't already the case, that it is a state of emergency. The state speaks in many ways, and displaying political symbols is one of them (Brettschneider, 2012; Tsai, 2016). In virtue of being a form of state speech, political symbols have authority. For example, when the Australian government decided that Australia Day is to (continue to) be 26 January, the day the First Fleet arrived at Sydney Cove and initiated the "[d]ispossession, discrimination, disadvantage, and death" (Pearson \& O'Neill, 2009, p. 79) of Aboriginal and Torres Strait Islanders, it became and remains the case that 26 January is the day to "reflect on being Australian."

Note that political symbols do not have to be established by the state to be perceived as state speech. There are numerous statues and monuments donated by private organizations and displayed on public properties such as parks and roundabouts. Hemel and Ouellette's (2017) surveys reveal that people tend to perceive that the state conveys whatever messages or attitudes the privately established political symbols stand for, insofar as the state accepted the donations and continues to display them. As being perceived as instances of state speech, these privately established symbols also enjoy the authority of state speech.

State-sponsored political symbols often enjoy considerable publicity. Statues and monuments are often placed in some of the busiest intersections, and people cannot easily choose to ignore them. Historical figures the state memorializes are printed on currencies, and we have to carry them in our purses or wallets. When we contemplate or discuss where to go or how to get somewhere, what the state says through political symbols may also come into our thoughts. For example, when providing directions, we may say "take the green line north, transfer at the Chiang Kai-Shek Memorial Hall Station to the red line and head east, and after 5 stops you will arrive at Taipei 101." In a way, we are conscripted to become megaphones of state expression, and in this case, to repeat that the state memorializes Chiang.

Political symbols often speak indirectly. One paradigm was when the United States renamed its Department of War as the Department of Defense. "Defense," in contrast to "war," presupposes threats out there to be defended against (Goodin, 1980). Another example would be to use "Putonghua" or "Standard Chinese" to refer to Mandarin Chinese. ("Putonghua" literally translates into "the common/ordinary/normal speech.") This ranks Mandarin Chinese as superior and other languages such as Cantonese, Uyghur, and Tibetan as inferior, and legitimizes the relegation of those languages. ${ }^{4}$ Derogatory pedestalling introduced earlier is yet another oft-used way. For instance, prior to 1988, the "Legend of Wu Feng" was part of the national curriculum in Taiwan, in which Wu Feng was honored as "the man who civilized" the Indigenous Taiwanese. ${ }^{5}$ The thinly-veiled message was that the Indigenous Taiwanese are inferior, need to be saved by the civilized Han people, and that the forceful Sinicization policies are legitimate.

When the state speaks, it also speaks in the name of the people. For example, when the state expresses approval or disapproval of certain types of actions or ways of life through the law, it speaks as if it the people hold those attitudes (Sunstein, 1996; Arnold, 2000). The same is true of political symbols. To see this, one only has to consider what tourists who had minimal prior knowledge of a country would reasonably come to believe after she comes across a political symbol. For example, tourists who recently saw a Captain Cook statue engraved with "Captain James Cook Discovered Australia 1770" can reasonably infer that Australians hold such a belief and honor Captain Cook accordingly.

I would like to say slightly a bit more about the features of speaking indirectly and speaking in the name of the people, as these two features can lead to something particularly troublesome. According to George Tsai (2016), when the state exercises its expressive power through political symbols, it often makes the message harder to reject: 
states can mobilize symbols to subtly introduce presuppositions or background assumptions in this way-particularly when those symbols are deployed in ways that do not involve the provision of reasons-symbols are a powerful tool for shaping the beliefs and attitudes of citizens (p. 321).

To further elaborate, speaking in such manners suggests that the content is already part of the common ground and "does not need to be asserted outright" (Langton \& West, 1999, p. 309). The message also falls "outside the focus of conversational attention" (Camp, 2013, p. 341). Furthermore, it suggests that whatever spoken is the default. This exploits the human tendencies to "choose" the default (Johnson \& Goldstein, 2003), or do what their fellows do (Cialdini, 2007), or revise their opinions (even wrongly) in light of what others believe (Asch, 1955; Edelson et al., 2011). State-sponsored political symbols, therefore, tend to bypass our rational scrutiny, and is thus harder to reject. In addition, while individual hearers may want to disagree with what the state says, as state speech presumes to speak in the name of one's fellow citizens, without further evidence indicating otherwise, it is reasonable for an individual to come to have the belief that such views are widely endorsed. (This need for counter-evidence also explains the need to say "not in my name" or "not my president" out loud when one disagrees with state (sponsored) speech, which will become highly relevant later in the paper.)

State-sponsored tainted symbols, for example, Captain Cook statues or the Chiang Kai-shek Memorial Hall, then, as instances of state speech, are able to degrade, alienate, or cause or constitute other forms of expressive harm with the authority of the state, become parts of everyone, including the victims', everyday life, and furthermore speak in their name. This normalizes the inferior status of target groups, and bars easy escapes from the derogatory messages constantly expressed. This furthermore forces the victims to constantly contemplate on and convey their own inferiority. Furthermore, as the derogatory messages are spoken in the name of all members of the society, victims will then have to choose between participating in their own degradation and alienation, or being unable to see themselves as members of the society. These features, in combination with "derogatory pedestalling" introduced earlier, make the derogatory message of state-sponsored tainted symbols more forceful. All that being said, understanding these features will also help us see how these symbols can be resisted by the actions of private actors.

\section{3 | POLITICAL VANDALISM AS COUNTER-SPEECH}

In 2017, Australians answered the national postal survey "Should the law be changed to allow same-sex couples to marry?" with an overwhelming yes. Many supporters, however, opposed holding this survey in the first place. One reason was that having such a survey and nationwide debate would provide platforms for haters. Unfortunately, this fear proved to be well founded. For example, "VOTE NO!" graffiti appeared in various public spaces. However, in Lanyon Valley, Canberra, a particularly interesting counter-graffiti appeared: by altering the "!" into a "W," someone transformed the original graffiti into "VOTE NOW."6

There were a number of interesting things going on. The counter-graffiti was in a way aesthetically pleasing, however ugly it was, as some sort of irony was present, as if the "VOTE NO!" was predestined to become "VOTE NOW." The counter-graffiti might also have been (retributively) satisfying, as this message of hatred was turned against the haters. However, I will omit these potentially fruitful discussions, to focus instead on how speech can be "undone" by counter-speech, and apply this to countering state-sponsored tainted symbols.

\section{1 | Counter-speech}

The basic idea of counter-speech is that in order for speech to do things, certain conditions-as J. L. Austin (1975) calls them, the felicity conditions-must hold, and that those conditions can sometimes be undermined by other speech. For instance, in everyday dialogue, presuppositions of assertions come to be part of the common ground of the conversation following what David Lewis (1979) calls the rule of accommodation for presupposition: 
If at time $t$ something is said that requires presupposition $P$ to be acceptable, and if $P$ is not presupposed just before $t$, then-ceteris paribus and within certain limits-presupposition $P$ comes into existence at $t$ (p. 340).

Using Lewis's example, saying "even George could win" in the context of watching sports is not just to communicate that "George could win," but at the same time presupposes and thus smuggles into the common ground the thought "George isn't a competent player." This instance of backdoor speech act, as Langton (2018a) calls it, succeeds when the audiences remain silent and continue to listen or proceed with the conversation as if there wasn't anything wrong with the "even." However, as Langton observes, if someone questions the presupposition by simply asking, in this case, "what do you mean by 'even'," the backdoor speech acts is blocked: automatic accommodation no longer occurs, and the speaker has to justify the presupposition for it to be accepted.

This model of accommodation and blocking is not limited to presuppositions. ${ }^{7}$ Most notably, people can speak as if they have authority, and gain the relevant authority through the silence of others (Langton, 2018b; Maitra, 2012). This is how hate speech and pornography can have authority despite being regarded as "low types:" they presume authority with regard to the status of people of color and women, and insofar as others remain silent, they gain the requisite degree of authority to successfully rank people as inferior. In response, others, especially bystanders, can sometimes speak back through things like "speak for yourself" or even a simple "hey" and challenge the presumed authority.

In addition, Langton points out that sometimes refusing to acknowledge the authority certain speakers typically enjoy can help to undermine their authority. For example, when Rosa Parks, and of course Claudette Colvin 9 months before her, refused to move when demanded to give their seats to white passengers, they acted as if the demand had no authority. ${ }^{8}$ Their acts by themselves were insufficient to undermine the state's authority, but "[i]t was a protest, and part of a movement, a cumulative series of acts done with other speakers and actors-including, in the end, the authoritative speech of a greater law, which overturned the sign's authority" (Langton, 2018a, p. 151). Noncompliance is to act as if the authority does not have authority, and once this "nonauthority" is accommodated by others, it becomes the case that the purported authority lacks authority.

It should be noted that there are often many obstacles and difficulties against the effectiveness of individual counter-speech. For one, agents who intend to engage in counter-speech may lack the relevant authority to speak in ways that will be taken seriously by others. This may be because they already belong to marginalized groups (Langton, 2018a), or suffer from testimonial injustice (as Fricker (2007) characterizes it), such that their speech would not be believed or trusted. Or it may be because one lacks the skills and abilities to effectively recognize and challenge problematic speech, such as "the epistemic ability to identify the presuppositions; the clarity to challenge them in a way that makes it more difficult for others to twist one's words" (Lepoutre, 2017, p. 896), etc. For these and various other reasons, it may be preferable that the state takes on the task to engage in counter-speech (Lepoutre, 2017). However, in the following, I will highlight a possibility of effective private counter-speech against state-sponsored derogatory pedestalling. While this may seem to be an uphill battle, I will show that privately engaged vandalism can sometimes be effective and in turn the most appropriate means of tackling state-sponsored tainted symbols.

\section{2 | Political vandalism "undoes" tainted symbols}

Regardless of the best efforts of seeking dialogue, sympathizers of tainted symbols are not always willing to remove or even to consider clarifying tainted symbols with plaques or counter-monuments. Furthermore, "[i]n public debate, symbolic politics...are often ridiculed...[as] politics for those privileged enough to ignore what really matters" (Schulz, 2019, p. 167). In such cases where the prospects of official removals or counter-monuments are dim and "more speech" gets us nowhere, I propose that political vandalism-the unauthorized defacement, destruction, or removal of political symbols-sometimes serves as an effective form of counter-speech. This will pave the way for the permissibility, and even the duty, to vandalize. 
First, tainted symbols often enjoy considerable publicity. ${ }^{9}$ They stand out. They are highly visible. Through defacing, destroying, or removing them, something as salient as the political symbols themselves comes into being. For example, in Taiwan Chiang Kai-shek statues are vandalized annually around 28 February, the anniversary of the 228 Massacre that took place in 1947. Decapitating the statue, (spray-)painting graffiti with messages like "butcher" and "unforgivable," or dressing statues up with humiliating outfits, makes sure that every time someone receives the message of pedestalling, a disagreement, a counter-message, or a ridicule is also received.

Compare this to other forms of dissent. Petitions might in the long run lead to the removal of tainted political symbols. But they do not neutralize them immediately. Furthermore, they often do not work, at least on their own. By contrast, removals of prominent political symbols have been initiated by acts of vandalism. For example, the earlier mentioned Legend of Wu Feng was removed from the national curriculum after thirty people of the tribe of Tsou tore down the Wu Feng statue in Chiayi, Taiwan in 1988, and it is this act of political vandalism that kickstarted a nationwide debate which eventually led to the removal of Wu Feng symbols. The toppling and drowning of the statue of the slave trader Edward Colston has also led to the reevaluation and removal or renaming of other racist political symbols in the UK. ${ }^{10}$ Constant protests around political symbols might meet some degree of publicity the symbols have. However, never-ending protests are often too demanding for those assaulted by the symbols, and it is highly unfair that those who already suffer from unjust harm bear heavier burdens just to spare objects liable to be destroyed from being damaged. In addition, while large scale protests may be more effective than individual acts of vandalism (though it may not necessarily be so), in terms of "effectiveness per participant" it surely is not. The publicity of one act of vandalism, something that can be carried out by one single activist, can match the publicity of a statue or monument. Other things being equal, the most effective method seems preferable.

Second, through derogatory pedestalling, tainted symbols indirectly declare that the oppressed matter less, and rank them as inferior. Political vandalism, especially those that provide counter-messages, can help to challenge the problematic indirect content, and prevent the otherwise automatic accommodation. "Black Lives Matter" graffiti on Confederate monuments, for example, challenge derogatory messages of black inferiority not by pointing out that people misidentified who have fought and died for "the lost cause," but by making vivid the fact that the Confederacy was founded upon slavery.

Third, state-sponsored tainted symbols speak in our name. This excludes those who are unable to identify with the speech from being part of the people. Political vandalism, in response, makes it clear that others also disagree with the message, and pushes back against the presumption that the message or attitude expressed by the tainted symbol is something everyone endorses. This can also amount to sending a message of solidarity to the alienated: "you are not alone."

Fourth, state-sponsored tainted symbols have the authority of the state. Political vandalism directly challenges the authority of tainted symbols. It not only refuses to pay respect to authority, but actively displays disrespect by treating those symbols as something to be destroyed or ridiculed. This is an attempt to make others unable to take the tainted symbols seriously, to presume "nonauthority" while seeking the accommodation of others-which may include explicitly expressed support for the vandal(s), or indifference and the lack of support for restoration-so to render tainted symbols practically inert. In contrast, protests that leave tainted symbols untouched may leave room for the interpretation that while protesters disagree with the derogation, it is ultimately up to the state or the majority to decide whether the social hierarchies or the exclusion should persist. Thus, and especially when the tainted symbols continue to stand, protests fail to challenge the authority forcefully enough.

\section{3 | The necessity condition}

Even if nothing short of political vandalism works to mitigate the immediate and lasting pernicious effects of tainted symbols, we still need to bear in mind that political vandalism ranges from easily removable defacements such as dressing statues up with humiliating outfits or stickers with counter-messages, to more permanent damages such as spray-painting, decapitation, destruction, or removal. How can the more disruptive acts be appropriate vis-à-vis the 
necessity condition-something widely endorsed in the ethics of war and self-defense that no force more than necessary to avert an evil is permissible? ${ }^{11}$

First, effectiveness varies. Easily removable counters may just allow the symbols to continue to express derogatory messages immediately after simple restoration or cleaning. Against lasting political symbols, vandalism needs to stick, sometimes literally. This is why more disruptive acts of vandalism are often called for. Defacement, decapitation, destruction, and removal constitute more enduring forms of counter-speech.

Second, opportunities and risks involved in engaging in vandalism vary. Activists often need to get away from the scene as soon as possible to avoid being caught or becoming targets of violent responses, or they only have the opportunity to engage in hit-and-run tactics. Assuming that they plan to do something effective, a bucket of paint and a dozen eggs may well serve as good options. It should be noted, however, that sometimes the personal costs of vandalism may indeed be prohibitively high, but such costs can at most generate an agent-centered prerogative against a duty to vandalize (which will be discussed shortly), but cannot by itself make an otherwise permissible act impermissible. Other things being equal, personal costs are relevant to the obligation and mere-permissibility distinction, not to the permissibility and impermissibility distinction.

Third, sometimes distorting tainted symbols beyond recognition is called for. Consider the linguistic behavior of slurs. There is an interesting linguistic phenomenon that when reporting, indirect quotations that contain slurs are rarely acceptable, whereas direct quotations often are. ${ }^{12}$ Suppose Fox News said, "Jeremy is a chink," and we want to make a complaint. It is less acceptable for us to say, "Fox News said that Jeremy is a chink," or "Fox News was wrong, Jeremy is not a chink." Instead, we should say "Fox News (inappropriately) called Jeremy a 'chink'." The difference between acceptable and unacceptable reports often concerns whether the slur is put in quotations. When it is in quotations, the speaker mentions the slur; if not, the speaker uses it, even if the speaker is just reporting what someone else said. Mentioning, in contrast to using, exercises the force of slurs a lot less. Thus, putting things in quotations insulates the objectionable force better (Bolinger, 2017; Hornsby, 2001; Williamson, 2009).

However, insulation does not always work. Sometimes there is a "leak," and the quotation does not completely prevent the slurs from being forceful (Anderson \& Lepore, 2013; Langton, 2018a). This is why we do not normally spell out the n-word, not even in quotations, but refer to it with "the n-word" (unless we are, say, writing papers directly engaging with the behavior or morality of slurs, or teaching about them, where the context makes it absolutely clear that we are not exercising the force of the n-word). The analogy goes back to tainted symbols. In certain cases, lesser forms of counters do not bracket the tainted symbols enough. Dressing a statue of Chiang Kai-shek up in humiliating outfits may appear funny to many, covering his statue up with red paint may make vivid the blood on his hands, but the knowledge that the honoring of him remains and will eventually be restored can still unease many of his victims. The force still "leaks" out. This concern is especially salient when past instances of vandalism have been quickly restored, and the security of the tainted symbols upgraded thereafter. In such cases, destruction or even total removal would be necessary to render tainted symbols unrecognizable and impotent.

In sum, political vandalism ranges from defacement, destruction, to total removal, where some acts are more disruptive than others. In addition, certain types are more communicative and more informative, and seek to persuade the majority for the case of removal; while others are more coercive, and rely more on the prohibitive costs of restoration. Other things being equal, the less disruptive and more communicative acts are preferable. However, what the most fitting option is depends on various factors. When less disruptive measures are less effective such as when dialogic attempts have been exhausted or proven to be futile, when we need to stop the derogatory messages then and there, or simply because less disruptive opportunities do not present themselves, more is called for.

\subsection{A pro tanto duty to vandalize}

I intend to go a step further and suggest that citizens may have a pro tanto duty to vandalize, that is, unless there are strong countervailing reasons speaking against vandalism (e.g., personal costs), citizens will acquire an all things 
considered duty to vandalize. There may be several different grounds for the duty to resist one's own oppression (Boxill, 1976, 2010; Hay, 2013; Hill, 1973), or the duty to prevent the oppression of others (Delmas, 2014b, 2014a; Wellman, 2005). The duty to vandalize tainted symbols may just be a special instance of those duties. However, there is something special about accommodation I wish to single out.

Tainted symbols succeed in doing derogatory things because they are accommodated. Sometimes, this is because we accommodate them. Ayala and Vasilyeva (2016) argue that an interlocutor who remains silent when problematic presuppositions provides the conditions without which the problematic presuppositions cannot come into being. Thus, one's silence actually contributes to part of the harm that is done through presuppositions, and one can thus be held at least in part morally responsible for the harm. In the case of state sponsored tainted symbols, all who pass by are the interlocutors of such instances of state speech. Their silence, or in many cases our silence provides the conditions upon which the indirect speech is accommodated. Furthermore, the authority the state enjoys is also sustained by the continual accommodation of its people, of us. Therefore, should the state successfully degrade or alienate through political symbols, those who fail to challenge either the content or authority are to be held (at least partially) responsible. Thus, one has reason to challenge tainted political symbols; and without sufficiently strong countervailing reasons, one gains a duty to challenge tainted symbols. As political vandalism sometimes serves as the most appropriate way to counter tainted symbols, it is sometimes the proper way to cash out this duty of nonaccommodation. This gives us a pro tanto duty to vandalize.

This pro tanto duty may be defeasible in a number of ways. Most notably, the personal costs one might incur when engaging in this type of illegal action might override the pro tanto duty. Whether they do depends on a number of factors, such as the risk of being caught, the severity of the punishment, and whether such acts would be legally protected by the freedom of speech and expression clauses or receive other types of legal exemptions. ${ }^{13}$ In the case of being fined for acts of vandalism, it also depends on whether others are willing to sponsor the vandals.

However, even in cases where this pro tanto duty is overridden by personal costs, personal costs would unlikely make this otherwise required act impermissible. On the contrary, such acts would become supererogatory and thus optional. In addition, the personal costs that prevent political vandalism from being obligatory might redirect the reasons supporting vandalism to demand something else. Another duty may emerge, say, a duty to show disrespect towards tainted symbols. For example, a while ago there was a photo that went viral on social media, inducing the outrage of many conservative Americans. The photo depicted three "migrants" giving the middle finger to Mount Rushmore National Memorial. It turned out that those "migrants" were actually Native Americans, who's sacred mountain had been violated by European migrants. The Native Americans surely have a legitimate complaint against the national memorial. ${ }^{14}$ I suggest that others doing something similar would sometimes be a fitting way to (at least partially) fulfil this duty to show disrespect. While individually showing disrespect is far less effective in comparison to political vandalism, it is most often costless and at least to some extent works against the harms of tainted symbols. Therefore, even when we are exempt from the duty to vandalize, the derived duty to display disrespect may still firmly hold.

\section{4 | OBJECTIONS}

Nonpolitical vandalism is typically impermissible. Some might object that political vandalism is similarly morally problematic. In the following, I will consider and respond to several objections.

\section{1 $\quad$ Beyond civil disobedience}

It is often said that in a sufficiently just society, illegal political activities must stay within the boundaries of civil disobedience; they must be conscientious, public, nonviolent, communicative, and display a willingness to accept legal consequences (Brownlee, 2012; Rawls, 1999; Sabl, 2001). Political vandalism falls short of this standard. Therefore, political vandalism is impermissible. 
But the idea of a categorical ban on "uncivil" forms of disobedience is at the very least questionable (Delmas, 2018; Lai, 2019). ${ }^{15}$ Indeed, we might instead argue as follows: Political vandalism is sometimes justified. Political vandalism falls short of civil disobedience. Therefore, civil disobedience is too strict a requirement. There is good reason to accept the alternative argument. Requiring publicity would greatly diminish the prospects of success of political vandalism, and solidifies the harms of tainted symbols. Requiring punishment acceptance is effectively placing additional obstacles to hinder the struggle against injustice. Overplaying the importance of civility runs the risk of "deter[ing] noncompliance and reinforc[ing] the status quo" (Delmas, 2018, p. 23). To avoid prematurely dismissing potentially justified social struggles, the best way forward may be to cease focusing exclusively on whether an act is civil and ask instead whether it is justified-say, in virtue of realizing the values that typically support obeying the law in ways within the limits of proportionality and necessity (Lai, 2019).

More specifically, sometimes incivility has its own value. Langton (2018a) points out that "[t]o block is to flout co-operative norms, violate regulative rules about conduct in good conversation" (p. 160). Exposing and/or challenging presuppositions derails the conversation, and is outrightly impolite. However, to civilly wait for the conversation to end and then seek to mitigate the expressive harm is not always feasible. Sometimes the opportunity to block vanishes, as the accommodation of the harmful speech is already complete. Similarly, seeking to remedy tainted symbols via civil disobedience or other civil conducts may simply miss the point. Civility demands that we respectfully, sometimes too respectfully, plea for and then wait for change to happen rather than force change to happen ourselves (Markovits, 2005; Moraro, 2014; Smith, 2011, 2013). When we wait for change (that may be unlikely) to happen, we are at best allowing the tainted symbols to continue to harm, and may even run the risk of accommodating the harm. The incivility of political vandalism, in contrast, has the value of blocking the harms of tainted symbols then and there. To insist upon civility and civil disobedience simply ignores the unique value incivility sometimes presents. ${ }^{16}$

\subsection{Erasing history}

One often-raised objection is that political vandalism erases history. For example, Malcolm Turnbull, then Prime Minister of Australia, condemned political vandalism as "a deeply disturbing and totalitarian campaign to not just challenge our history but to deny it and obliterate it." He also equated it with the burning of historical scripts, and Stalin's execution and removal of all official photos of people who fell out of his favor. ${ }^{17}$ The accusation, in short, is that political vandalism erases and whitewashes history.

My response is very simple. Political vandalism can erase historical records as much as authorized removals of tainted symbols can. If it is already the case that a particular tainted symbol ought to be officially removed and destroyed, political vandalism is no more problematic in terms of erasing. Furthermore, and luckily, the records are most often well kept. If one looks into books, the internet, or museums, evidence of history can be easily found. What political vandalism and authorized removals do is merely to prevent tainted symbols from continuing to express derogatory messages. In addition, while it is important to preserve samples of derogatory pedestalling to help current and future generations recognize past injustice and witness moral progress, preservation is compatible with both official removal and political vandalism. Enough samples may already be preserved in museums, and adding vandalized monuments to the collection may even reflect historical struggles more accurately.

\section{3 | Violating free speech}

Some might be tempted to say that the inappropriateness of political vandalism lies in its interference with the speech of others. Accordingly, the display of political symbols is a form of speech, and is thus protected by the freedom of speech, one of the fundamental liberties. 
The most straightforward reply is that there are limits to the freedom of speech. Hate speech falls beyond the scope of this fundamental liberty, for hate speech causes or constitutes harms to others (Maitra, 2012; Waldron, 2012). Tainted symbols-the target of political vandalism-harm in ways similar to hate speech, and some do so more forcefully with the authority of the state. Therefore, vandalizing tainted symbols does not violate the freedom of speech.

Some might insist that despite its wrongfulness, individual hate speech should nevertheless be protected: the freedom of speech involves something like Jeremy Waldron's (1981) "moral right to do wrong," where even if it is wrong to express pro-attitudes towards severe injustice, others have a duty to not interfere. Thus, people might have the right to privately display tainted political symbols. However, this right by no means entitles people to have their speech adopted by the state as one of the official statements. Therefore, insofar as political vandalism is targeted against state-sponsored tainted political symbols, it does not seem to be a violation of the freedom of speech.

\section{\begin{tabular}{l|l}
4.4 & Tolerance
\end{tabular}}

Demetriou and Wingo (2018) hold that "[e]very people needs its heroes, and any people with a developed material culture will remember them with monuments" (p. 351). What needs to be done, accordingly, is to commemorate the overlooked history and culture of traditionally oppressed groups, rather than to tear down racist monuments. Demetriou and Wingo further write, "efforts to cleanse the landscape of racist monuments are unacceptably damaging to civic cohesion and will ultimately frustrate anti-racist goals" (p. 351) and that "healthy racially diverse citizenry, will want their cohabitants to feel free to honor their ancestors and draw pride in their heritage" (p. 352). Political vandalism, some might thus hold, is intolerant and will threaten social harmony.

Furthermore, for sympathizers of tainted symbols, any act of removal, be it official removal or private vandalism, would give them a sense of being threatened. However unreasonable this sense is, it can be real, and can thus threaten future social harmony. Demetriou and Wingo highlight the fact that certain Southerners have the genuine worry of being "replaced," or that the politics is a zero-sum game (p. 348), where the removal of symbols they identify with is just the first step leading to their foreseeable, from their point of view, ominous future. In contrast, allowing certain symbols to stand may send a much-needed friendly message that can facilitate future social harmony.

Two responses. First, I am unsure whether we genuinely need "heroes" to facilitate social harmony. But, even if we do, I doubt that tolerating tainted symbols and telling the already disadvantaged to endure is "healthy." Especially when tainted symbols send forceful derogatory messages because they possess the relevant authority and publicity, demanding tolerance from the victims seems to do nothing but to perpetuate the unjust status quo, and perpetuating the unjust status quo is highly counterproductive to future social harmony. Indeed, we need to be cautious about the apparent promotion of liberal ideals that in effect undermine liberal ideals (Stanley, 2015). In this case, fairness is compromised in the name of tolerance, as the demand of tolerance here is to require the already disadvantaged to bear unequal burdens for the sake of (an arguably unjust) harmony.

Second, even if we really need to celebrate heroes for the sake of social cohesion, we can surely find heroes whose conducts instantiate values the current generation can endorse, or at least not strictly oppose. It seems highly unlikely that great people in the history, either recent or far in the past, of any country, have all actively engaged or participated in unjust or oppressive activities. While such heroes may not be relevant to everyone, we can certainly find some of whose deeds are worth celebrating, and furthermore belong to groups whose oppressive "heroes" are (to be) removed. Once we find them, and celebrate them in the name of the state, the friendly message that all citizens are equal can be sent, and the clarification that no one is to be "replaced" can be made. It should, of course, be noted that it may not be the business of the vandals to find heroes for (the descendants of) their former oppressors. Doing so would be the business of the state or (the descendants of) their former oppressors. However, highlighting the possibility where all get to celebrate their own heroes without committing derogatory pedestalling simply shows that neither official removals nor political vandalism is incompatible with future social harmony. 


\subsection{Inciting unfavorable reactions}

Vandalism is a form of violence and there is a general aversion to violence. Resorting to vandalism may drive away potential sympathizers. Furthermore, those who identify with desecrated symbols might be inclined to retaliate. Most notably, the decision to remove the Charlottesville Robert E. Lee sculpture lead to white-supremacist rallies and violent attacks against counter-protests, which resulted in several severe injuries and the death of the civil rights activist Heather Heyer. If authorized removals already incite violence, unauthorized desecrations most likely would lead to more. Given that the removal of political symbols runs the risk of inciting atrocious actions, it is best avoided.

This is a good reminder of the need to proceed judiciously and with caution. However unfair, sometimes the wrongful reactions of others can make an otherwise permissible action impermissible. Thus, if resorting to political vandalism does indeed drive away potential sympathizers and make social struggles more difficult, or incites violence and puts the innocent in danger, it may well be prudent to refrain from political vandalism. ${ }^{18}$ At the same time, this is hardly going to be true in each and every case. It may very well be that the public is apathetic, and there are few potential supporters to be driven away. "Behaving" and refraining from vandalism may serve nothing of great value. Similarly, the threat of retaliatory violence may not be credible. Typically, there is sufficient legal protection against such violence. Furthermore, when there is a lingering threat of (racial) violence (especially when it is not unequivocally repudiated by state actors), violent incidents may be likely to occur one way or another. Controversies surrounding political symbols may take the blame, but this does not mean they are the genuine cause.

\section{5 | CONCLUSION}

State-sponsored tainted symbols ought to be confronted, removed, or at least recontextualized. I have argued that when official confrontation does not take place, political vandalism-the unauthorized defacement, destruction, or removal of political symbols-may be called for. This is because political vandalism appropriately counters the features of state-sponsored tainted symbols. Political vandalism challenges the authority of these symbols in a way that matches their publicity, refuses to allow them to speak in our name, and exposes and sometimes refutes the indirect derogatory messages expressed through derogatory pedestalling. In short, when all else fails, political vandalism as a form of uncivil disobedience is justified insofar as it "undoes" the harms of state-sponsored tainted symbols. We may have a duty to vandalize, and when this duty is defeated by personal costs, we may then have a duty to display disrespect towards tainted symbols.

\section{ACKNOWLEDGMENTS}

I would like to thank Nicholas Southwood, Philip Pettit, Seth Lazar, Justin Bruner, Renee Bolinger, Ishani Maitra, Robert Goodin, Shen-yi Liao, Sheri Kim, Lachlan Umbers, Kimberley Brownlee, William Smith, Candice Delmas, Massimo Renzo, Shmuel Nili, Hanti Lin, Miranda Fricker, Louise Richardson-Self, Karen Fox, Jeffrey Howard, Joanna Burch-Brown, Vince Redhouse, the audiences of UNSW Philosophy Seminar (2018) and ANU Philsoc Seminar (2018), participants of the ANU MSPT Graduate Workshop (2018), and some of the anonymous referees for helpful, constructive, and relevant comments. This research is supported by an Australian Government Research Training Program (RTP) Scholarship.

\section{ORCID}

Ten-Herng Lai (D) https://orcid.org/0000-0001-9760-2240

\section{ENDNOTES}

${ }^{1}$ Discussion of political vandalism is absent from, for example, Brownlee (2012), Milligan (2013), Smith (2013), and Celikates $(2014,2016)$ on civil disobedience, and Delmas (2018) on uncivil disobedience. I have very briefly hinted that 
political vandalism might be a type of justifiable type of violent uncivil disobedience, but have not gone into the details (Lai, 2019). Schulz (2019) mentions a case of vandalism, but merely uses it to highlight the significance of the morality of commemoration, and does not engage with the morality of vandalism, as the latter was not his focus. It should be noted that while Schulz does come to the conclusion that some commemorations ought to be removed, and that we ought to confront tainted commemorations, further argument is needed to justify the permissibility and obligation of unauthorized direct actions. To see this, just consider the fact that while we may agree that the state ought to make public classified records that conceal state injustice and war crimes, or that we ought to seek to shut down environmental unfriendly industries, whether it is permissible or even obligatory to engage in direct actions such as whistleblowing (Boot, 2019; Delmas, 2015) or eco-sabotage (Vanderheiden, 2005) is debatable. (An anonymous referee pressed me to clarify how the difference between the removal of monuments and vandalism is not "merely verbal." The substantial difference is between official actions taken by the state and private citizens taking matters into their own hands.) Lim (2020), which was published during the revision of this manuscript, is a notable exception. Lim, however, rejects the justifiability of destroying or removing monuments and only endorses acts of defacing such as covering statues with red paint, does not entertain the possibility of a duty to vandalize, and explicitly points towards the possibility that acts of vandalism may be all things considered impermissible due to failing to meet the standards of civil disobedience. This paper directly engages with all these issues.

2 Sui, C. (13 March 2016). Taiwan Kuomintang: Revisiting the White Terror years. BBC. https://www.bbc.com/news/worldasia-35723603.

${ }^{3}$ The Australia Day website https://www.australiaday.org.au/about-australia-day/history/.

${ }^{4}$ It would be a simple mistake, however, to hold that the suppression of language is the worst the people of Hong Kong, Uyghur, and Tibet face.

${ }^{5}$ Cheung, H. (2017) Taiwan in Time: The drastic downfall of Wu Feng. Taipei Times. http://www.taipeitimes.com/News/ feat/archives/2017/09/10/2003678150. For more on the Legend of Wu Feng and how it is a blatant lie used to legitimize Sino-centrism in Taiwan from 1960s to 1980s, see Wu (2017).

${ }^{6}$ Lanyon Valley's Facebook Page: https://www.facebook.com/lanyonvalley/posts/2021118814832582.

7 We can easily build accounts of how the phenomena of conversational implicatures (Swanson, Forthcoming), dogwhistles (Saul, 2018), and racial-figleaves (Saul, 2017), just to name a few, may follow the same pattern: some less than direct message is conveyed, and can gain force through accommodation unless some counter-speech takes place.

8 "[Claudette] Colvin was the first person to be arrested for challenging Montgomery's bus segregation policies, so her story made a few local papers-but 9 months later, the same act of defiance by Rosa Parks was reported all over the world." Rumble, T. (10 March 2018). Claudette Colvin: The 15-year-old who came before Rosa Parks. BBC. https://www.bbc. com/news/stories-43171799.

9 There may be neglected tainted symbols hidden in bushes in public parks. They are less of my concern insofar as people have not rediscovered them. However, the risk of their discovery may give us good reason to preemptively remove them.

10 Ellery, B. (11 June 2020).Toppling of slave trader Edward Colston starts domino effect across country. The Times. https:// www.thetimes.co.uk/article/black-lives-matter-toppling-of-slave-trader-starts-domino-effect-across-country-0wlvbgldf

11 The necessity condition is much more complicated than merely demanding the least harmful means to avert threats. Morally weighted harms and prospects of success, among other things, also play significant roles in the calculation. See, for example, Lazar (2012).

12 There may be other uses of slurs that are acceptable, especially when used by in groups, say, when slurs are used in a "cacophemistic," that is, course, rough, or vulgar manner, rather than a "disphemistic," that is, pejorative, manner (Corlett, 2005, 2018); or when slurs are reclaimed through reappropriation (Anderson, 2006; Bianchi, 2014). It is unclear whether oppressed groups can reclaim or reappropriate tainted symbols, but even if they can, they do not obviously to have a duty to do so. In addition, it seems obvious that tainted symbols as they currently are, have not gone through reappropriation. Thus, I will leave this important possibility aside in the following discussion of the leakage of the force of certain derogatory symbols.

${ }^{13}$ For instance, in 2018 two defendants were acquitted of all charges for vandalizing a bronze statue of Chiang Kai-shek in Yangmingshan National Park, for the statue was donated by private groups and not considered public property. This acquittal may just be an exception though. Pan, J. (28 Sep 2018). Court drops case against vandals of Chiang statue. Taipei Times. http://www.taipeitimes.com/News/taiwan/archives/2018/09/28/2003701315.

14 Cotton, R. (10 Aug 2017). Viral Photo of People Giving Middle Finger to Mount Rushmore Causes Outrage. Inquisitor. https://www.inquisitr.com/4423814/viral-photo-of-people-giving-middle-finger-to-mount-rushmore-causes-outrage/.

15 We might also question whether our societies are indeed sufficiently just. Lyons (1998) warns against disregarding severe injustice while demanding dissidents to act as if the society were sufficiently just. 
16 The expression of anger can sometimes serve important epistemic functions, for example, highlight the severity of the injustice (Lepoutre, 2018). Arguably, the incivility of vandalism can contribute to the expression of such anger.

17 Malcolm Turnbull's Facebook: https://www.facebook.com/malcolmturnbull/posts/10155761463461579.

18 This may be a case of affective injustice where the oppressed are forced to choose between acting on apt anger on one hand, and acting prudentially on the other hand. See Srinivasan (2018).

\section{REFERENCES}

Anderson, E. (2006). The epistemology of democracy. Episteme, 3(1-2), 8-22.

Anderson, L., \& Lepore, E. (2013). Slurring words. Noûs, 47(1), 25-48.

Arnold, N. S. (2000). Postmodern liberalism and the expressive function of law. Social Philosophy and Policy, 17(01), 87-109.

Asch, S. E. (1955). Opinions and social pressure. Scientific American, 193(5), 31-35.

Austin, J. L. (1975). How to do things with words, London: Oxford university press.

Australian Institute of Health and Welfare. (2019). Understanding Indigenous Welfare and Wellbeing, Australia: Australian Government. https://www.aihw.gov.au/reports/australias-welfare/understanding-indigenous-welfare-and-wellbeing.

Ayala, S., \& Vasilyeva, N. (2016). Responsibility for silence. Journal of Social Philosophy, 47(3), 256-272.

Bianchi, C. (2014). Slurs and appropriation: An echoic account. Journal of Pragmatics, 66, 35-44.

Bolinger, R. J. (2017). The pragmatics of slurs. Noûs, 51(3), 439-462.

Boot, E. R. (2019). The ethics of whistleblowing, London: Routledge.

Boxill, B. R. (1976). Self-respect and protest. Philosophy \& Public Affairs, 6(1), 58-69.

Boxill, B. R. (2010). The responsibility of the oppressed to resist their own oppression. Journal of Social Philosophy, 41(1), 1-12.

Brettschneider, C. (2012). When the state speaks, what should it say?: How democracies can protect expression and promote equality, Princeton: Princeton University Press.

Brownlee, K. (2012). Conscience and conviction: The case for civil disobedience. Oxford, England: OUP.

Burch-Brown, J. (2017). Is it wrong to topple statues \& rename schools? Journal of Political Theory \& Philosophy, 1(1), $59-86$.

Camp, E. (2013). Slurring perspectives. Analytic Philosophy, 54(3), 330-349.

Celikates, R. (2014). Civil disobedience as a practice of civic freedom. In On Global Citizenship. James Tully in Dialogue (pp. 207-228). London: Bloomsbury.

Celikates, R. (2016). Democratizing civil disobedience. Philosophy \& Social Criticism, 42(10), 982-994.

Cialdini, R. B. (2007). Influence: The psychology of persuasion. New York, NY: Collins.

Corlett, J. A. (2005). For all my Niggaz and bitches: Ethics and epithets. In Hip hop and philosophy (pp. 147-157). Illinois: Open Court Publishing.

Corlett, J. A. (2018). Offensiphobia. The Journal of Ethics, 22(2), 113-146.

Delmas, C. (2014a). Political resistance: A matter of fairness. Law and Philosophy, 33(4), 465-488.

Delmas, C. (2014b). Samaritanism and civil disobedience. Res Publica, 20(3), 295-313.

Delmas, C. (2015). The ethics of government whistleblowing. Social Theory and Practice, 41(1), 77-105.

Delmas, C. (2018). A duty to resist: When disobedience should be uncivil, New York: Oxford University Press.

Demetriou, D., \& Wingo, A. (2018). The ethics of racist monuments. In Palgrave handbook of philosophy and public policy. Palgrave Macmillan.

Edelson, M., Sharot, T., Dolan, R. J., \& Dudai, Y. (2011). Following the crowd: Brain substrates of long-term memory conformity. Science, 333(6038), 108-111.

Fitzgerald, J. (2009). Why are indigenous imprisonment rates rising. In Crime and justice statistics. Sydney, Australia: NSW Bureau of Crime Statistics and Research.

Fricker, M. (2007). Epistemic injustice: Power and the ethics of knowing, New York: Oxford University Press.

Frowe, H. (2019). The duty to remove statues of wrongdoers. Journal of Practical Ethics, 7(3).32-53.

Gelber, K., \& McNamara, L. (2016). Evidencing the harms of hate speech. Social Identities, 22(3), 324-341.

Goodin, R. E. (1980). Manipulatory politics, New Haven: Yale University Press.

Hay, C. (2013). The obligation to resist oppression. In Kantianism, liberalism, and feminism (pp. 117-157). London: Springer.

Hemel, D., \& Ouellette, L. (2017). Public perceptions of government speech. The Supreme Court Review, 1, 33-92.

Hill, T. E. (1973). Servility and self-respect. The Monist, 57(1), 87-104.

Hornsby, J. (2001). Meaning and uselessness: How to think about derogatory words. Midwest Studies in Philosophy, 25(1), 128-141.

Johnson, E. J., \& Goldstein, D. (2003). Do defaults save lives?. Science, 302(5649), 1338-1339.

Lai, T.-H. (2019). Justifying uncivil disobedience. In Oxford studies in political philosophy, 5, 90-114). New York: Oxford University Press.

Langton, R. (2018a). Blocking as counter-speech. New Work on Speech Acts, 144-164). New York: Oxford University Press. 
Langton, R. (2018b). The Authority of Hate Speech. Oxford Studies in Philosophy of Law, 3, 123-152). New York: Oxford University Press.

Langton, R., \& West, C. (1999). Scorekeeping in a pornographic language game. Australasian Journal of Philosophy, 77(3), 303-319.

Lazar, S. (2012). Necessity in self-defense and war. Philosophy \& Public Affairs, 40(1), 3-44.

Lepoutre, M. (2017). Hate speech in public discourse: A pessimistic defense of counterspeech. Social Theory and Practice., 43, 851-883.

Lepoutre, M. (2018). Rage inside the machine: Defending the place of anger in democratic speech. Politics, Philosophy \& Economics, 17(4), 398-426.

Lewis, D. (1979). Scorekeeping in a language game. Journal of Philosophical Logic, 1, 339-359.

Lim, C. (2020). Vandalizing tainted commemorations. Philosophy and Public Affairs, 48(2), 185-216.

Lyons, D. (1998). Moral judgment, historical reality, and civil disobedience. Philosophy \& Public Affairs, 27(1), 31-49.

Maitra, I. (2012). Subordinating speech. In Speech and harm: Controversies over free speech (pp. 94-120). New York: Oxford University Press.

Markovits, D. (2005). Democratic disobedience. Yale Law Journal, 114(8), 1897-1952.

Milligan, T. (2013). Civil disobedience: Protest, justification and the law, London: Bloomsbury Publishing.

Moraro, P. (2014). Respecting autonomy through the use of force: The case of civil disobedience. Journal of Applied Philosophy, 31(1), 63-76.

Nili, S. (2020). From Charlottesville to the Nobel: Political leaders and the morality of political honors. Ethics, 130(3), 415-445.

Pearson, W., \& O'Neill, G. (2009). Australia day: A day for all Australians? In National Days: Constructing and Mobilising National Identity (pp. 73-88). London: Palgrave Macmillan.

Rawls, J. (1999). A theory of justice, London: Oxford University Press.

Sabl, A. (2001). Looking forward to justice: Rawlsian civil disobedience and its non-Rawlsian lessons. Journal of Political Philosophy, 9(3), 307-330.

Saul, J. M. (2017). Racial figleaves, the shifting boundaries of the permissible, and the rise of Donald Trump. Philosophical Topics, 45(2), 97-116.

Saul, J. M. (2018). Dogwhistles, political manipulation, and philosophy of language. New Work on Speech Acts, $360,84$.

Schulz, J. (2019). Must Rhodes fall? The significance of commemoration in the struggle for relations of respect. Journal of Political Philosophy, 27(2), 166-186.

Smith, W. (2011). Civil disobedience and the public sphere. Journal of Political Philosophy, 19(2), 145-166.

Smith, W. (2013). Civil disobedience and deliberative democracy, London: Routledge.

Srinivasan, A. (2018). The aptness of anger. Journal of Political Philosophy, 26(2), 123-144.

Stanley, J. (2015). How propaganda works, Princeton: Princeton University Press.

Sunstein, C. R. (1996). On the expressive function of law. University of Pennsylvania Law Review, 144(5), 2021-2053.

Swanson, E. (Forthcoming). Slurs and ideologies. In Ideology: New essays, London: Oxford University Press.

Taylor, J. E. (2006). The production of the Chiang Kai-shek personality cult, 1929-1975. The China Quarterly, 185, 96-110.

Timmerman, T. (Forthcoming). A case for removing confederate monuments. In Ethics left and right: The moral issues that divide us, London: Oxford University Press.

Tsai, G. (2016). The morality of state symbolic power. Social Theory and Practice, 42(2), 318-342.

Vanderheiden, S. (2005). Eco-terrorism or justified resistance? Radical environmentalism and the "War on Terror". Politics and Society, 33(3), 425-447.

Waldron, J. (1981). A right to do wrong. Ethics, 92(1), 21-39.

Waldron, J. (2012). The harm in hate speech, London: Harvard University Press.

Wellman, C. H. (2005). Samaritanism and the duty to obey the law. In Is There a Duty to Obey the Law (pp. 3-89). Cambridge: Cambridge University Press.

Williamson, T. (2009). Reference, inference and the semantics of pejoratives. In The Philosophy of David Kaplan (pp. 137158). London: Oxford University Press.

$\mathrm{Wu}, \mathrm{M}$. (2017). Moral education and the aboriginal peoples of Taiwan: From Sino-centrism to the ethic of multiculturalism. Journal of Moral Education, 46(1), 69-78.

How to cite this article: Lai T-H. Political vandalism as counter-speech: A defense of defacing and destroying tainted monuments. Eur J Philos. 2020;28:602-616. https://doi.org/10.1111/ejop.12573 